\title{
Bringing back emotion, imagination and the senses: Creative writing in journalism research
}

Cristina Archetti, University of Oslo

\section{Creative writing for academic purposes}

In the last fifteen years, across the social sciences, there has been a proliferation of creative writing applications to research. Examples of this trend, which has recently been referred to with the umbrella term of 'poetic enquiry' (Prendergast et al. 2009), can be located across a range of disciplines, from nursing and social work, to anthropology, geography and feminist studies, just to name a few (Prendergast 2009: xxi). Monica Prendergast, in compiling a detailed annotated bibliography of existing academic research incorporating elements of creative writing finds not only that Poet's Corner sections figure regularly on the pages of a range of peer-reviewed journals (e.g., Social Work, American Anthropologist, or the Journal of Interdisciplinary Studies) (2009: xx), she also identifies a sheer variety of terms and practices: among 40 different labels she lists are 'data poetry', 'field poetry', 'researchgenerated poetry', 'poetic analysis', ‘investigative poetry'...(2009: xx-xxi).

This development, which is based on both acknowledging and exploiting for analytical purposes a researcher's engagement with the senses, feelings and the surrounding reality, also reflects a broader attention in the humanities at large towards materiality, practice and emotions. These aspects have become the subject of study and debate, respectively, in the socalled 'material turn' (Hicks 2010), 'practice turn' (see e.g., Schatzki et al. 2001) and the ‘emotional turn' (for instance, Davidson and Milligan 2007). Ivan Brady, an anthropologist whose poetry has been widely published in academic journals and books, talks about research complemented by the use of poetry as an 'artful science' (2004). Paul Stoller, another well- 
known name within this investigative genre, writes of 'sensuous scholarship' (1997, 2004). Both authors refer to the opportunity offered by creative writing to account for the 'plurality of meaning that we experience' (Brady 2004: 632). They particularly emphasize the need to overcome the Cartesian separation between mind and body that has been at the root of the development of modern science. As they explain, because human beings, and with them the researcher, are both sensual and intellectual creatures (Brady 2004: 624; Stoller 1997: xi-Xv), academic enquiry alone is able neither to capture nor to convey the full complexity of reality. In this respect sensuous scholarship, as 'a mixing of head and heart' (Stoller 1997: xviii), is a more comprehensive research practice.

This article examines thus the role of creative writing in understanding journalism. It argues that non-academic writing - poetry in this case - can play a much more significant part in journalism research than that of an entertaining genre for disseminating a study's findings, mainly to audiences beyond academia. Not only can poetry complement traditional 'academic' texts by filling the gaps of the vivid details of the situated practices of journalism as they are lived in real life. It also has far-reaching epistemological and ontological implications: it raises, in other words, fundamental questions related to what we assume the world where journalists operate to be, the role of imagination, sensory perceptions and emotions in everyday practice, as well as the very place of the scholar in the research process. The benefits of creative writing are illustrated through examples of actual poems written while conducting a comparative investigation of foreign journalists' practices in the United Kingdom, Norway and Eastern Africa.

\section{Poetry and journalism: Not an odd couple}


Poetry and journalism would seem, at first glance, at the opposite ends of the writing spectrum. Especially in the Anglo-Saxon world, journalism tends to be seen as being about objectivity, the facts, the detached observation, 'bearing witness' to history. This is regarded as the quasi-scientific enterprise of revealing truths which 'stay the same no matter who speaks about them' (Burt 2013: n.p.). Poetry, on the contrary, is most strongly associated to subjectivity, art, the uniquely personal and creative viewpoint of the writer, the sphere of emotions. Yet this tension between activities, professional missions and ways of writing that, one would think, are so clearly and diametrically opposite, is only illusory (Archetti 2013b).

To start with, over history, there have been plenty of examples of journalists who were also poets (Nelson 2007). We can think of Archibald MacLeish, who both received multiple awards (including two Pulitzer Prizes) for his poetry and worked part-time for Time, the Toronto Star and Fortune (Nelson 2007: 166-68). Henry Luce, founder of both Time and Fortune, was in this respect convinced that it was 'easier to turn poets into business journalists than to turn bookkeepers into writers' (Nelson 2007: 170).

These stories are more than coincidences dictated by the need, as it has often been the case, of exploiting one's writing skill to pay the bills or the fact that both poetry and journalism respond to events - think of war poetry about World War II (Roberts 1996) or writing inspired by 9/11 (Johnson and Merians 2011, for one example) - and, more broadly, to life. Poetry and journalism ultimately share the same aim of engaging the reader and revealing that what is not immediately apparent. As Irish political journalist and writer Olivia O'Leary wrote talking about the Northern Ireland conflict: 'Journalism and poetry at their best try to state the truth. Journalism and poetry at their worst do the opposite' (cited in Greenslade 2011). 
There are several examples of projects where poetry has been used to contribute to journalism, particularly to invite the public to observe everyday life with different eyes (Anon. 2009; NPR 2012). In February 2014, to make one example, the San Francisco Chronicle, the Centre for Investigative Reporting and the young residents of a public housing in San Francisco were brought together in 'Off/Page', a project designed to encourage the reporting of issues that would normally not make the news through innovative forms of storytelling (Off/Page 2014).

It can be argued, however, that all good journalism involves to some extent a poetic angle. Beyond merely informing the reader through the who, what, where and when of a news beat - which nowadays could even be written by a robot (Clerwall 2014) - good journalism is ultimately about enabling understanding. And this, in a world saturated with information, where our attention is dulled by both the amount of distractions and the impression of having heard it all before, needs to include the how and what it feels like (Burt 2013).

This is indeed confirmed by the foreign correspondents I talked to. As Tristan McConnell foreign correspondent based in Nairobi who works for The Times of London, Monocle and the Global Post among other organizations - describes his writing:

I do not want to bore the readers quoting from a bunch of reports or anything like that. What the reader wants is to share the experience of being in that place with me, so I try to put as much colour and description [...] as I can. If I am writing a story, you know, about following the British ambassador [in Somalia] I want the reader to feel like they are sitting in the car with us. (2015) 
Here is what he actually wrote in reporting that story for AFP, powerfully describing the atmosphere as one arrives at Mogadishu's airport: 'The four-square kilometre (1.5 square mile) base is a bizarre expatriate ecosystem of muscled and tattooed private security contractors, ambitious young diplomats, jaded aid workers, furtive spies, uniformed soldiers and businessmen with an unusually high-risk threshold' (McConnell 2015).

\section{Creative writing about journalism: The benefits}

So there is a connection, in the writing practice and even in the aims of showing a hidden reality to the reader, between poetry and journalism. But why writing creatively about journalism? Creative writing and storytelling could be used not only to promote greater public involvement with academic research. They are also an opportunity for researchers to reflect on their data. In this section I am spelling out the methodological benefits of creative writing in journalism research. They are accompanied by examples of poems that illustrate different ways in which creative writing can complement academic texts.

Poem 1, related to a comparative study of foreign correspondents in London and Oslo (Archetti 2014c), particularly highlights the thinking processes of the researcher and the opportunity to bring the interviewees to life through anecdotes and small details that would have not been included in the academic text. Poems 2 and 3 are used to create a vivid and sensorial picture of key locations where correspondents covering Eastern and sub-Saharan Africa research their stories: poem 2 refers to Mogadishu (Somalia); poem 3 to Nairobi (Kenya), where most foreign correspondents are based. The focus here is highlighting the deceptive nature of the environments the journalists work in, both highly safe and - 
especially for white westerners - highly dangerous, as well as giving the reader a sense of what it feels like to be there.

\section{A first opportunity for the researcher to reflect on the data}

Poem 1 is one example of a set of creative pieces I wrote, each, straight after an interview. My aim was to write them on the basis of what I remembered from the exchange with the journalist. Each piece simply had to loosely revolve around the focus of my study - the way the environment, including the organization of the urban space, affects the newsgathering routines and practices of foreign journalists. These poems were not only a first opportunity to reflect on what I had heard and my experience but also, as I found out, a way to do so in a free and unconstrained way. As such, poem 1 reflects what I instinctively perceived as important and worthy of attention, as well as some of the questions that popped into my mind. Both poem 1 and 2 borrow from 'found poetry' (Glesene 1997; Lahman and Richard 2013) in so far as they rearrange the interviewee's words.

\section{A context for innovation}

The practice of creative writing can work as a method for establishing more imaginative connections among ideas and reading unusual patterns in the data gathered. As Melanie Jasper writes, 'reflective writing enables the researcher to draw together and express fledgling ideas and connections and build these as they become more substantial' (2005: 252).

\section{Map the evolving thinking of the researcher}

The poems make apparent those gut feelings and impressions that inevitably guide the researcher in the interpretation of the results. As Ivan Brady explains, objectivity is 
'fictional': 'because all research necessarily starts with an observer moving through the world as personally situated sensuous and intellectual being' (2009: xi). Providing these verbal sketches is a way to document the thinking processes and perhaps even the emotional aspects of research that would otherwise be hidden. This ultimately enables to researcher to achieve greater intellectual honesty. The poems, in this sense, are the equivalent of stating who funded the research at the end of an article to make more transparent the processes through which conclusions were drawn from the data - what again Melanie Jasper calls 'a verifiable audit-trail of the research process' (2005: 250, original emphasis).

\section{Bring back the 'researcher' into the research}

Academic writing removes the ' $\mathrm{I}$ ' from the writing in the attempt to present findings as objective. However, as Stefanos Mantzoukas explains, although the positivist paradigm is based on the belief that bias can be eliminated, this is never possible: 'all research starts not just from anywhere, but from somewhere specific, and that is the specific individual researcher' (2005: 284). As he continues: 'To suggest that the researcher can be the central figure of the research, responsible for every decision made regarding the study, and at the same time argue that those decisions did not bear the researcher's personal input is [...] schizophrenic' (2005: 290-91).

\section{Poem 1}

'London - 20 minutes to the City/1 minute to oblivion'

20 minutes train journey

from Surbiton to the City. 
If anything happens on the way

there is always the internet

or an iphone

to catch it.

8 hours time difference to Japan

means tweeting late at night

her 8,000 followers

who like

to read her lines

early in the morning.

She write for websites, magazines, a blog,

the Huffington Post Japan,

Yomiuri Shinbun, radio, TV

a column on Yahoo.

Technology, celebrity,

human interest:

what Japan likes to know,

and how the country is seen

from the outside world.

I have stopped asking old questions.

They hardly apply any more: 
'Do you use newsagencies?'

If I think that it seemed interesting

just two years ago...

News leads, she says,

come from: the Guardian, the Financial Times,

the Economist, the $B B C$

the 2,000 organizations she follows on Twitter

her colleagues friends'

the Facebook newsfeed.

She gets financial rewards

from media in print,

only scrapes little writing for the net.

Sure she can live,

albeit she'll never be rich.

Struggling to add the value

of the knowledge matured

for having lived 12 years

in the same place

- although when consumers are so busy

is there any quality at all to produce?

One might have taken three days 
to research a story.

Yet, no matter how good the article is,

'after a minute'

it is forgotten.

Complement the academic piece of research, i.e. the traditional article or conference paper that has been produced as a result of a study

The poems offer an opportunity to include what did not 'fit' into the academic article, in this case offering a rounder, more nuanced, and perhaps more entertaining view of the practices described in the article and the locations in which they take place. As Bloor writes, 'sociological poetry' can 'capture the imagination and convey the human meanings of social facts' (2012: 43).

\section{Bring back vividly the 'individual' and the 'everyday' into academic research}

The poems offer a glimpse, albeit fleeting, into the life of the correspondents who have been interviewed. There is a tendency in academic research, in its attempt to achieve generalization of results, to strip people of their individuality. In so doing academic researchers also drain real life from their data. In the poem the interviewees are being brought back to life through their voices as people, not just as 'sources of data' of a journal article. The creative writing pieces thus restore what Paul Stoller calls the 'choppiness of everyday life' (1992: 508). 
Poem 2: This example of found poetry is based on an e-mail exchange with a Somali journalist and former politician.

'Exchange'

It feels so odd

for us Somalis

to meet people like you

who came to help Somalia

and we could not invite you for a meal

at a restaurant

or take you for a walk

around the city

with its nice beaches.

Poem 3

'Nairobi - It's All Fine'

No $\operatorname{HEFAT}^{1}$ certificate,

I nervously sign

the compulsory waiver

of liability claims.

It's all fine:

We will not abandon you in the field

if something goes amiss. 
I have attached

the State Department's

crime and safety report

for your use and consideration.

Please understand

that many Americans

visit Kenya every day.

At the airport in Nairobi

people smile 'jambo' and 'welcome'

with warm light in their eyes.

I wait for my driver outside

envying hairstyles that defy gravity,

watching girls laugh

in colourful dresses.

It's all fine.

Practice good situational awareness,

don't wander down dark alleys

always walk with someone else

and you should be safe

for the time of your visit.

Guards and bollards

and a brand new red light

at a checkpoint 
before the fortified gates

of my hotel.

High-voltage barbed wire

hides behind the tropical plants

(I have only before seen in my mum's pots)

of five-acres landscaped gardens

and the iconic water feature

advertised on TripAdvisor.

A British diplomat,

I later find out,

is not allowed to overnight here:

safety measures

do not meet

the FCO's ${ }^{2}$ standards

after all.

It's all fine.

The hotel is located

in one of the safest neighborhoods

very close to the Israeli Embassy,

which has extremely tight security.

Bulging iron barrels

filled to explosion point

with concrete

line the entrance 
to a restaurant's car park.

'How are you today?' politely asks the man

inspecting the boot

and the passengers' seats

with a torchlight.

It's all fine.

We were just doing our shopping

says the woman

whose husband

was shot

in front of her eyes

at the Westgate Mall.

\section{Conclusion: The deeper questions}

This article is an invitation to question what we know about journalism: to realize that there are issues related to objectivity in conducting research that go beyond the mere correct application of a methodology; that a considerable part of the reality and practices of journalism we study can be neither captured nor expressed through academic enquiry (and texts) alone.

The poems helped me understand that I, as a researcher who should have been objective and detached, was in reality a product of all my previous life history combined: of all the literature I had read, of my own experimentation with creative writing (Archetti 2013a, 2014d, 2014f), of nearly 40 conversations with foreign journalists, of my contribution 
(Archetti 2014e) to a poetry festival (Mamilla International Poetry Festival, Ramallah, October 2013), of my stays in Mogadishu and Nairobi meeting NGO workers and professionals engaged in countering violent extremism, of having taken a ride in an armoured vehicle... Just like my interviewees - foreign journalists working in the United Kingdom, Norway and the African continent - were the product of unique constellation of relationships that involved people, technologies and material infrastructure and this affected their practices - as I concluded in my academic writing, so was I. This meant that, within the research process, I was far from a neutral collector of information.

Writing poetry also primed me towards paying more attention to feelings and emotions. I started realizing that the very extent to which I was able to extract information from my interviewees did not depend on the mere execution of the 'elite interview techniques' I had been so thoroughly trained in. The 'success' of a conversation depended not so much on the structuring of my questions or on making sure I fitted them in the time available to the interviewee. A 'good interview' depended to a much greater extent on a subtle chemistry based, on either side, on varying degrees of trust, curiosity, a liking of the other person and gut feeling. Emotion and sensory perceptions during an interview seemed to be playing a crucial role. Why had I never paid attention to this before as a methodological aspect? How would have my data changed had it been a 'bad interview' day for either me or the interviewee? What was really my role as an investigator in the research process? What was the nature of the data that I had gathered? Was the very interview material really objective information that I had picked and categorized according to systematic criteria, as I had always believed - or had I in fact co-created it with my interviewees? To what extent did my findings truly reflect the reality of the everyday practices lived by the correspondents I had 
interviewed rather than my own bias? Was my study 'scientific'? Indeed, could any investigation claim to be so?

Ultimately, the most important lesson of 'sensuous scholarship', as Stoller puts it, is that of 'humility': 'No matter how learned we may become, no matter how deeply we have mastered a subject, the world, for the sensuous scholar, remains a wondrous place that stirs the imagination and sparks creativity' (1997: 136).

\section{References}

Anon. (2009), 'When writers and poets reported the news', Guardian, 15 June, http://www.theguardian.com/books/booksblog/2009/jun/15/fiction-poetry. Accessed 10 May 2015.

Archetti, C. (2013a), 'Distances', in W. Brown (ed.), LS13: A New Generation of Leeds Writers, Scarborough: Valley Press, pp. 39-45.

(2013b), 'What's creative about creative writing?', The Leeds Big BookEnd, http://theleedsbigbookend.wordpress.com/2013/10/04/whats-creative-about-creative-writing/. Accessed 10 May 2015

(2014c), 'Journalism and the city: Redefining the spaces of foreign correspondence', Journalism Studies, 15:5, pp. 586-95. 
(2014d), 'Foreigner', in S. Cashman (ed.), Poems for Mamilla, Dublin: Otherworld

Press Pamphlets, p. 54, http://www.archjerusalem.com/wp-content/uploads/2014/10/Poems-

for-Mamilla-ARCH-Anthology-October-2014.pdf. Accessed 17 April 2015.

(2014e), 'Walls', in S. Cashman (ed.), Poems for Mamilla, Dublin: Otherworld Press

Pamphlets, pp. 8-9,http://www.archjerusalem.com/wp-content/uploads/2014/10/Poems-for-

Mamilla-ARCH-Anthology-October-2014.pdf. Accessed 17 April 2015.

(2014f), 'Urban mythology', in S. Burnett and J. Kite (eds), Spokes: Poetry on Two

Wheels, Otley: Otley Word Feast Press, p. 55.

Bloor, M. (2012), 'The rime of the Globalised mariner: In six parts (with bonus tracks from a chorus of Greek shippers)', Sociology, 47:1, pp. 30-50.

Brady, I. (2004), 'In defense of the sensual: Meaning construction in ethnographic poetics', Qualitative Enquiry, 10:4, pp. 622-44.

(2009), 'Foreword', in M. Prendergast, C. Leggo and P. Samshima (eds), Poetic Inquiy: Vibrant Voices in the Social Sciences, Rotterdam: Sense Publishers, pp. xi-xvi.

Burt, S. (2013), 'Poetry: The news that stays news', Nieman Reports, 67:1, Spring, http://niemanreports.org/articles/poetry-the-news-that-stays-news/. Accessed 15 April 2015.

Clerwall, C. (2014), 'Enter the robot journalist: Users' perceptions of automate content', Journalism, 8:5, pp. 519-31. 
Davidson, J. and Milligan, C. (2007), 'Embodying emotion sensing space: Introducing emotional geographies', Social and Cultural Geography, 5:4, pp. 523-32.

Glesene, C. (1997), 'That rare feeling: Re-presenting research through poetic transcription', Qualitative Inquiry, 3:2, pp. 202-21.

Greenslade, R. (2011), 'Which tells the greatest truth - poetry or journalism?', Guardian, 28 March, http://www.theguardian.com/media/greenslade/2011/mar/28/seamusheaney-irishtimes. Accessed 20 January 2015.

Hicks, D. (2010), 'The material cultural turn: Event and effect', in M. C. Beaudry and D. Hicks (eds), The Oxford Handbook of Material Culture Studies, Oxford: Oxford Univesity Press, pp. 25-99.

Jasper, M. (2005), 'Using reflective writing within research', Journal of Research in Nursing, 10:3, pp. 247-60.

Johnson, D. L. and Merians, V. (eds) (2011), Poetry After 9/11: An Anthology of New York Poets, Brooklin, NY: Melville House.

Lahman, M. K. E. and Richard, V. M. (2013), 'Appropriated poetry: Archival poetry in research', Qualitative Inquiry, 20:3, pp. 344-55. 
Mantzoukas, S. (2005), 'The inclusion of bias in reflective and reflexive research', Journal of Research in Nursing, 10:3, pp. 279-95.

McConnell, T. (2015), 'Firing squads, blast walls and dangerous diplomacy in Somalia', Mail Online, 25 February, http://www.dailymail.co.uk/wires/afp/article-2968046/Firing-squadsblast-walls-dangerous-diplomacy-Somalia.html. Accessed 12 May 2015.

Nelson, W. D. (2007), Gin Before Breakfast: The Dilemma of the Poet in the Newsroom, Syracuse, NY: Syracuse University Press.

NPR (2012), 'Newspoets: Writing the day in verse', http://www.npr.org/series/156006378/newspoet. Accessed 10 April 2015.

Off/Page (2014), 'About', http://youthspeaks.org/offpage/about/. Accessed 22 April 2015.

Prendergast, M. (2009), 'Introduction: The phenomena of poetry in research', in M. Prendergast, C. Leggo and P. Samshima (eds), Poetic Inquiy: Vibrant Voices in the Social Sciences, Rotterdam: Sense Publishers, pp. ix-xlii.

Prendergast, M., Leggo, C. and Samshima, P. (eds) (2009), Poetic Inquiy: Vibrant Voices in the Social Sciences, Rotterdam: Sense Publishers.

Roberts, D. (ed.) (1996), Minds at War: The Poetry and Experience of the First World War, Burgess Hill: Saxon Books. 
Schatzki, T., Knorr, C. K. and von Savigny, E. (eds) (2001), The Practice Turn in Contemporary Theory, London: Routledge.

Stoller, P. (1992), 'Review of anthropological poetics by Ivan Brady', American Anthropologist, 94:2, pp. 508-09.

(1997), Sensuous Scholarship, Philadelphia: University of Pennsylvania Press.

(2004), 'Sensuous ethnography, African persuasions, and social knowledge', Qualitative Enquiry, 10:6, pp. 817-35.

\section{Contributor details}

Dr Cristina Archetti is Associate Professor in Political Communication and Journalism at the University of Oslo, Norway. She is interested in communication in politics and society, including: international journalism and foreign correspondence; the impact of new communication technologies on the practices of politicians and diplomats; the role of the media in conflict and in the phenomenon of transnational extremism. She is also a creative writer of poems and short stories.

Contact:

Dr Cristina Archetti

University of Oslo

Postboks 1093 Blindern

0317 Oslo

Norway

E-mail: cristina.archetti@media.uio.no 
Notes

\footnotetext{
${ }^{1}$ Hostile Environment First Aid Training.

${ }^{2}$ Foreign and Commonwealth Office.
} 